\title{
Qualitative Evaluations of the AlSi7Mg0.3 Microstructure by the X-Ray Diffractometry
}

Jan Lago ${ }^{1}$, Ondřej Řidký², Otakar Bokůvka ${ }^{1}$, František Nový1

${ }^{1}$ University of Žilina, Faculty of Mechanical Engineering, Department of Materials Engineering, Univerzitná 8215/1, 010 26 Žilina. E-mail: jan.lago@fstroj.uniza.sk

${ }^{2}$ Faculty of Mechanical Engineering, Technical university in Liberec. Student 1402/2, 46117 Liberec I. Czech Republic. E-mail: ondrej.ridky@tul.cz

Nowadays it's very important to minimalize the costs of casted parts, what obviously conclude to reduction in time that is necessary for the heat treatment. Despite this fact it's necessary to keep or moreover increase mechanical properties like a strength, ductility, toughness and dimensional stability. Better mechanical properties lead to the better material utilisation, this parameter is represented by the following formula: $Q=R_{m}+k \cdot \log A_{5}$, known as a Quality index and increase of this parameter conclude to weight reduction of casted part. For obtaining good quality of the casted part it's very important to watch the cast's internal composition, hence the microstructure of the casted part. For the facts mentioned above, this paper deals with evaluation of the microstructure of aluminium alloy AISi7Mg0.3 by an X-ray diffractometry using the Debye-Scherrer method with configuration for rebound reflection and comparison of the results with metallographic observations using the light microscopy. Work is showing the opportunities of the $X$-ray diffraction for the nondestructive material testing of the casted aluminium parts, because in this field there are not enough knowledge about the comparison and evaluation between the microstructure and diffraction. Great advantage of the X-ray diffraction is that the testing surface doesn't needs to be specially treaded. This technology is non-destructive for the surface analyses so for the testing of the internal material composition it's necessary etching.

Keywords: AlSi7Mg0.3, X-ray, diffractometry, microstructure, evaluation

\section{Acknowledgement}

This research was supported by Scientific Grant Agency of the Ministry of Education, Science and Sports of the Slovak Republic and Slovak Academy of Sciences, grant No.: 1/0123/15 (50 \%) and No.: 1/0533/15 (50 \%).

\section{References}

[1] PEZDA, J. (2014). Influence of heat treatment parameters on the mechanical properties of hypoeutectic Al-Si-Mg alloy In: Metalurgija, Vol. 53, pp. 221-224.

[2] NÁPRSTKOVÁ, N., SVOBODOVÁ, J., CAIS, J. (2013). Modification of AlSi7Mg0.3 alloy by stroncium. In: Manufacturing Technology, Vol. 13, No. 3, pp. 373-380.

[3] KUCharíKOVÁ, L., TILlOVÁ, E., CHALUPOVÁ, M. (2016). The Si Particles Morphology in Hypoeutectic Al-Si Casts. In: Materials Today: Proceedings, Vol. 3, No. 4, pp. 1031-1036.

[4] HURTÁlovÁ, L., Tillová, L., CHALUPOVÁ. M. (2014). Optimization of eutectic Si particles morphology in secondary Al-Si cast alloys after different heat treatment. In: Advanced Materials Research, Vol. 1025-1026, pp. 349-354.

[5] TILlOVÁ, E., CHALUPOVÁ, M., HURTALOVÁ, L., BELAN, J. (2015). Impact properties of self-hardening aluminium alloy (Alzn10si8mg) at elevated temperatures, Manufacturing Technology, 15 (4), pp. 720-727.

[6] KUCHARIKOVÁ, L., TILLOVÁ, E., BELAN, J., UHRÍČIK, (2015). M. The effect of casting technology on Fe intermetallic phases in Al-Si cast alloys, Manufacturing Technology, 15 (4), pp. 567-571.

[7] HURTAlOVÁ, L., TILlOVÁ, E., CHALUPOVÁ, M., BELAN, J., VAŠKO, A. (2014). Microstructure control of secondary A 231 cast alloy used in automotive industry, Manufacturing Technology, 14 (3), pp. 326-333.

[8] HURTALOVÁ, L., TILLOVÁ, E. (2013). Elimination of the negative effect of fe-rich intermetallic phases in secondary (recycled) aluminium cast alloy, Manufacturing Technology, 13 (1), pp. 44-50.

[9] TROJAN, K. (2003). Difrakční studium vlivu laserového svařování na stav reálné struktury polykrystalických látek, Bachelor thesis. Praha: ČVUT.

[10] KRAUS, I., GANEV, N. (2004). Technické aplikace difrakčni analýzy. Praha: ČVUT. ISBN 80-01-03099-7.

[11] KRAUS, I., GANEV, N. (1995). Difrakčni analýzy mechanických napětí. PRAHA: ČVUT, 1995. ISBN 80-0101366-9. 
[12] ŘIDKÝ, O., GANEV, N., ZUZÁNEK, L., KOLAŘÍK, K. (2014). Rentgenografické difrakční stanovení povrchové distribuce makroskopických zbytkových napětí po laserovém svařování s přídavným materiálem. In: Strojírenská technologie, Vol. XIX, No. 2, pp. 112-118.

[13] ZUZÁNEK, L., GANEV, N., ŘIDKÝ, O., KOLǍ̌ÍK, K. (2014). RTG difrakční tenzometrická analýza oxidovaných povrchových vrstev ocelí. In: Strojírenská technologie, Vol. XIX, No. 2, pp. 136-143.

[14] TAYLOR, J. A., St-JOHH, D. H., COUPER, M. J. (2001). Solution Treatment Effects in Al-Si-Mg Casting Alloys: Part II: Solid Solution Chemistry. In: Aluminum Trasactions, Vol. 4-5, pp. 111-124.

[15] TIRYAKIOGLU, M., STALEY, J. T., CAMPBELL, J. (2004). Evaluating Structural Integrity of Cast Al-7\%SiMg Alloys Via Work Hardening Characteristics: II. A New Quality Index. In: Materials Science and Engineering $A$, Vol. 368, pp. 231-238.

[16] LI, H.J., SHIVKUMAR, S., LUO, X.J. APELIAN, D. (1989). Influence of Modification on the Solution HeatTreatment Response of Cast Al-Si-Mg Alloys. In: Cast Metals, Vol. 1 No.4, pp.227-234.

[17] EMADI, D., WHITING, L.V., SAHOO, M., SOKOLOWSKI, J.H., Burke, P., HART, M. (2003). Optimal Heat Treatment of A356.2 Alloy. In: Proc. Of the 132 the TMS Annual Conference, Light Metals 2003, The Mineral, Metals and Materials Society, San Diego, USA, pp. 983-989.

[18] SHIVKUMAR, S., RICCI, S. Jr., APELIAN, D. (1990). Influence of Solution Parameters and Simpified Supersaturation Treatments on Tensile Properties of Al-alloy. In: AFS Transactions, Vol. 98, pp.913-992. 